Short Communication

\title{
BIOMEDICAL WASTE MANAGEMENT - KNOWLEDGE AND PRACTICES AMONG HEALTHCARE PROVIDERS IN MANGALORE
}

\author{
Bhagya Bhaskar ${ }^{1}$, Hema Nidugala ${ }^{1}$, Ramakrishna Avadhani ${ }^{2}$ \\ ${ }^{1}$ Lecturer, Department of Anatomy, Yenepoya M edical College, Yenepoya University, India. \\ ${ }^{2}$ Professor, Department of Anatomy, Yenepoya M edical College, Yenepoya University, India. \\ Correspondence : \\ Bhagya Bhaskar \\ Lecturer, Department of Anatomy, Yenepoya M edical College, Yenepoya University, Deralakatte, University Road \\ M angalore - 575 018. Phone : 0824 - 2204668/69/70 E-mail : bagyabs@gmail.com
}

\section{Introduction :}

Advances in medical facilities with the introduction of sophisticated instruments has increased the waste generation per patient in health care units [1]. The rapid mushrooming of hospitals has increased the quantity of hospital waste production. Appropriate waste management system have been developed and installed globally to handle both hazardous and non-hazardous BioMedical Waste (BMW) [1]. The Ministry of Environment and Forests notified the Biomedical Waste (M anagement \& Handling) law in 1998 [2]. The infrastructure requirement for BM W management as per BMW rules is very expensive. Ramky a private firm offers services of handling hospital waste on pay and use basis [3]. They charge Rs. 500/- per month form clinics for collecting waste thrice per week. In India, hospital waste generated is about 1.59 to 2.2 $\mathrm{kg} / \mathrm{bed} /$ day [4]. Though many training programmes are conducted on BM W management for the health care team members and enforcing rules on handling them, improper regulation is continued by the hospitals, nursing homes, private practitioners etc. Thus a cross-sectional study was carried out to assess the knowledge and practices of health care providers in handling BMW in Mangalore city during January 2011.

\section{Methodology :}

A total of 216 health care providers were interviewed, out of which 58 were doctors, 62 nurses, 43 lab technicians and 53 non-teaching staffs. A semi structured questionnaire was used to elicit the information about knowledge regarding BMW management. About 68 private clinics were included in our study for practices regarding BMW disposal. Informal discussions with general practitioners on the management of medical waste were recorded.

\section{Results:}

Most of the interviewers were aware of the measures for safe collection, segregation and disposal of BM W. Highest percentage regarding knowledge on BMW management was seen among the nurses (61.3) followed by doctors (46.6), non-teaching staffs (37.7) and lab technicians (27.9) Fig 1. In M angalore total hospital waste generated ranges between 1.5 to 1.8 tons per day [3]. The general practitioners were of the opinion that disposing BMW is very expensive but cannot be compromised as the waste is hazardous and improper handling can lead to spread of infectious diseases. About $17.65 \%$ doctors continued to dump their medical waste into main municipal garbage or were landfilling them.

\section{Discussion \& Conclusion :}

From the above study we concluded that the knowledge and practice of BM W management was satisfactory among most health care providers. Yadavannavar et al [5] also stated a satisfactory report on BMW management practices among the staff of Bijapur Medical College. Pandit et al [6] reported that $86.6 \%$ of doctors were of the opinion that incineration is the best method of BMW disposal and all of the doctors interviewed were aware of the risk associated with hospital waste. Patil \& Pokhrel 2005 [7] reported about $2.31 \mathrm{~kg} /$ day/ bed of hospital waste being generated in Belgaum. In Bangalore total hospital waste produced ranges to about 40 tonnes per day and 1.5 $\mathrm{kg} /$ day/bed of medical waste is generated in Delhi [4] compared to 1.5 - 1.8 tons per day in M angalore [3]. 
In spite of enforcing strict BM W management law 1998 by the government a change in the attitude of the health care personnel is of prime importance in proper BMW management. Sharing the expenses of infrastructure requirement for hospital waste handling by government, public bodies and voluntary associations will help implement updated procedures and practices of medical waste management. It can also be attained only by commitment and support of the health care establishments which will ensure that there is no adverse health risks and environmental pollution. Including BM W management subject in the curricula of healthcare education will keep the health care personnel be informed about the risks associated with poor waste management systems and also about the scientific, safe and cost effective ways of handling BM W.

\section{Acknowledgements:}

The authors are grateful to Yenepoya University for permission to carry out thisstudy.

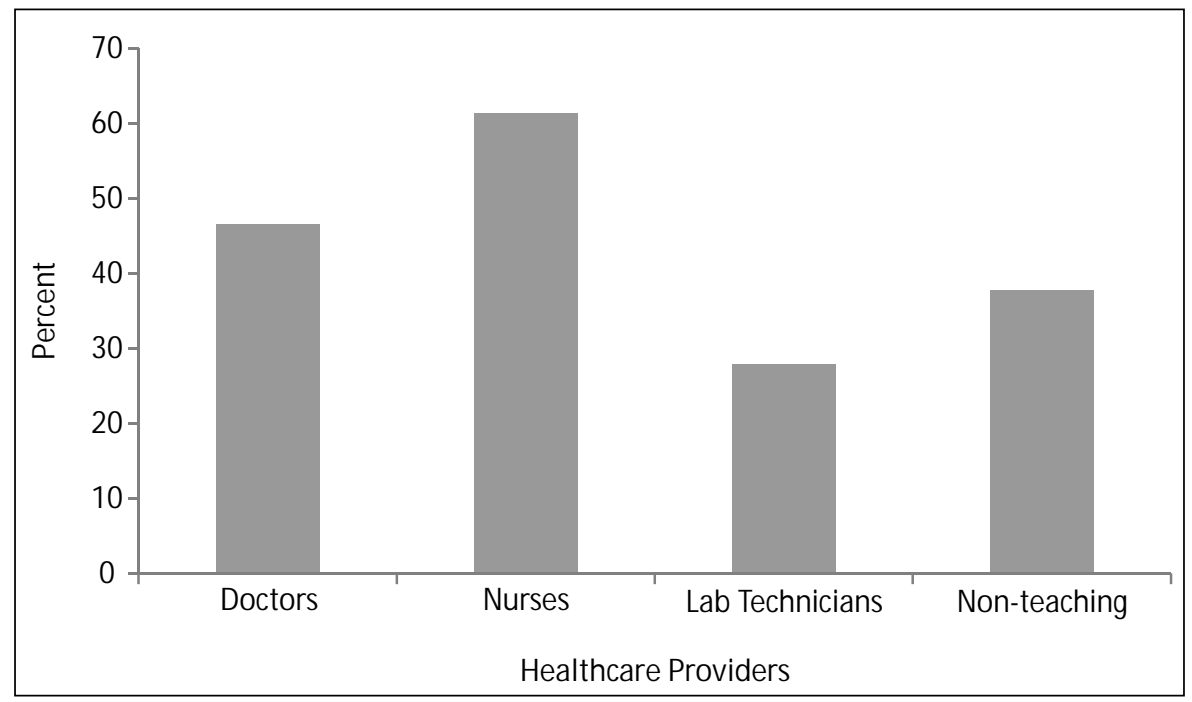

Fig 1: Percentage of knowledge regarding BM W management among Healthcare providers in Mangalore

\section{References:}

1. Radha KV, Kalaivani K, Lavanya R. A case study of Biomedical waste management in hospitals, Global journal of Health Science 2009; 1: $82-88$

2. Government of India. Biomedical waste (M anagement and Handling) Rules. 1998. Extraordinary, Part II, Section 3, Subsection (ii). The gazette of India, No. 460, 27 July 1998.

3. http://ramkyenviroengineers.com/BiomedicalWaste.html

4. http://www.ceetindia.org/modules/news/article. php? storyid=40
5. Yadavannavar MC, Aditya SB, Jagirdar PB. Biomedical waste management: A study of knowledge, attitude, and practices in a tertiary health care institution in Bijapur, Indian Journal of Community Medicine 2010; 35(1): 170-171.

6. Pandit NB, Mehta HK, Kartha GP, Choudhary SK. Management of biomedical waste: awareness and practices in a district of Gujarat, Indian Journal of Public Health 2005; 4: 245- 257.

7. Patil GV, Pokhrel K. Biomedical solid waste management in an Indian hospital: a case study, Waste M anagement 2005;25(6): 592 - 599. 